\title{
The Role of the Hashemite Scientific Councils in the Hashemite Kingdom of Jordan in Reflecting the True Image of Islam: Analysis of Content
}

\author{
Dr. Khyriah H. Shnaikat \\ Civil Service Department, \\ Princess Rahma University College, \\ Albalqa Applied University, Jordan
}

DOI: https://doi.org/10.36941/jesr-2020-0079

\begin{abstract}
The current study aimed at identifying the role of the Hashemite Scientific Councils in the Hashemite Kingdom of Jordan in reflecting the true image of Islam. Thecurrent study has the descriptive approach due to its suitability to the purposes of the study. The study sample was randomly selected from (48) councils from the Hashemite Scientific Councils held during (1999-2019). In order to collect data, the content exploratory analysis was applied, and it was found that the Hashemite Scientific Councils in the Hashemite Kingdom of Jordan had concern with religious topics with a percentage of (68\%) from the general content of the topics discussed by the Councils, while political topics have ranked second, followed by educational topics, social topics, economic topics, and finally human rights topics. The study recommended the necessity of generalizing the idea of the Hashemite Scientific Councils in the Arab and Islamic world, and activating the role of the Hashemite Scientific Councils by proposing new topics that match the requirements of the age of technology, as well as that the various media and communications shall adopt the message of the Hashemite Scientific Councils in disseminating the true image of Islam.
\end{abstract}

Keywords: Role, Scientific Councils, Islam

\section{Introduction}

Islam is the last of the heavenly religions - as it started with descend of the Angel of Revelation, Gabriel, peace be upon him, on the Prophet Mohammad, peace be upon him - who is (prophet Mohammad) known among his people for his honesty and good morals, in the cave of Hira. From that time the Prophet began to call for faith in Allah and spread Islam in the Arabian Peninsula and its surrounding in all ways and methods in order to rid people of idol worship and convert them to Allah worship. In this study, it is necessary to define Islam which is linguistically derived from the verb "surrender" in the sense of obedience and submission (Ibn Manzūr, 2010)." Allah said in the Holy Qur'an "Indeed, the religion in the sight of Allah is Islam", (QK, sec. 3, V. 19). As for religious scholars, they have defined Islam as "the latest heavenly religion that will last until al-Qiyamah "the Day of Resurrection". "Islam is the belief in all that the prophet Mohammad, peace be upon him, has brought. "The principles of Islam are reflected in its five pillars of Islam -the Five Pillars are the core beliefs and practices of Islam- on which it is based: Profession of Faith (shahada): The belief that "There is no god but Allah, and Mohammad is the Messenger of Allah", Prayer (salat), Alms (zakat), Fasting (sawm), Pilgrimage (hajj) (for whoever is able to find thereto a way). (Sherine T., 2016). 
Islam is a religion of moderation in belief, provisions, teachings, transactions, ethics, and interest in science and scholars, as the Islamic religion is an integrated approach in all aspects of religious, social, cultural, economic, health and political life.

The Ministry of Awqaf and Islamic Affairs, in Ramadan and for many years, has been setting up the Hashemite Scientific Councils with one council per week, specifically on Friday with the participation of a group of scholars in the Islamic religion from within the Hashemite Kingdom of Jordan and from the Arab and Islamic countries. These Hashemite Scientific Councils aim to educate Muslims about the matters of their religion and their life, in addition to other axes that include many scientific, religious, cultural and health topics that concern Muslims, and not to forget the concepts of moderation and tolerance emphasized by the Islamic religion,(ministry of Awqaf, 2020) in compliance with the instruction of Allah " Thus, have We made of you an Ummat (nation) justly balanced, that ye might be witnesses over the nations, and the Messenger a witness over yourselves " (Holly Quran, 2:143).

For years, the Hashemite Scientific Councils have been centres for science and knowledge, which focus on the correct understanding of the topics of religion and the developments of the era, in addition to thier call for the interdependence, unity and cohesion of the Islamic nation through its treatment of terms, topics and proposals that represent openness to achievements and benefit from all aspects of progress and use it to serve Islam and its topics.(Ghad newspaper, 25/5/2018), We would like to emphasize an important matter, which is that the Hashemite Scientific Councils are not the only experience in Jordan regarding topics of the Islamic nation and its interests. There are the "Amman Message" and "Interfaith Harmony Week", as the literature is constantly pioneer to clarify the tolerant message of Islam.

In this regard, we want to clarify the role of the Hashemite Scientific Councils in spreading the true image of Islam.

\subsection{Problem of the study}

The problem of the current study lies in discussing the role of the Hashemite Scientific Councils in disseminating the true image of Islam by analyzing their implications.

The study problem is summarized in the following main question:

What is the role of the Hashemite Scientific Councils in disseminating the true image of Islam, "A content analysis"?

The main question will be answered through the following sub-questions:

1. What are the implications of the Hashemite Scientific Councils in disseminating the true image of Islam?

2. What are the suggestions and recommendations that would further activate the role of the Hashemite Scientific Councils in disseminating the true image of Islam locally, on the level of Arab world, and globally?

\subsection{Objectives of the study}

The current study seeks to achieve the following objectives:

1. Identifying the implications of the Hashemite Scientific Councils in disseminating the true image of Islam.

2. Attempting to come up with suggestions and recommendations that would further activate the role of the Hashemite Scientific Councils in disseminating the true image of the Islamic religion locally, on the level of Arab world, and globally?

\subsection{The importance of the study and its justifications}

1. The importance and experience of the Hashemite Scientific Councils and their great role in 
disseminating the true image of Islam and disseminating its idea in the Arab and Islamic World.

2. The Islam exposure to distortion and hate speech, in addition to feelings of hostility to Islam and Muslims ,and the absence of dialogue between Muslims and other people of other religions.

3. The Muslim world has recently opened up to other societies as a result of global events and its need to change the stereotype of Islam and Muslims.

\subsection{Terminology of the Study}

The Hashemite Scientific Councils: Religious meetings held annually in the holy month of Ramadan with the participation of a group of scholars and preachers aiming to shed light on the topics that concern the Islamic nation, its unity and cohesion.

Islam: A person's belief that Allah is "the owner of the religion" and "He" must be worshipped through behaviors and Requisites of Islam.

Content analysis: A method of research that seeks to study media material in an accurate, objective and descriptive manner (A., K., Al-Debisi, 2017), and is used to measure and determine the amount of answers about a set of questions (Nisreen H., 2014).

\section{Literature Review}

A study carried out by (Rammal \& Mikhael, 2017) entitled "Religious Media Discourse". This study aims to shed light on the role that religious media owned by religious institutions play through political, religious, social and other messages, and their compatibility with the requirements of civil peace. The study found that most of the media messages broadcast by the religious media in question are based on the beliefs and values that religious media share with the community such media speaks in its name.

The religious and social discourse broadcast by the religious media serves as a special ideological starting point, although it denotes the partnership between religions, sects and denominations. The study recommended strengthening the discourse of religious moderation and transferring it from the individual situation of each institution to the overall situation, as well as working to remove religious culture from the circle of exploitation through the wrong mobilization that threatens civil peace and stability through the counter culture cultivated by extremist groups.

A study carried out by (Zayed, 2016) entitled "The Structure of Islamic Discourse: A Study in Content and Function" ; a brief study that intensifies consideration about Islamic discourse in terms of its structure and content, so it determines the vocabularies of this structure and its function in the discourse; and the purpose of this is to emerge in an integrated and balanced manner in the content, persuasion and change in the result, as the structure of Islamic discourse in its desired form according to the researcher's view - must include five major contents, namely: (general guidance content, values content, juristic content, intentional content, and sunnah content). Each of these contents has a function that should be paid attention in practice, so that the preacher moves from description to activation and operation of such contents.

A study carried out by (Abu Ghazaleh, 2013) entitled "Topics and goals of Islamic religious discourse in the Jordanian daily press: an analytical study". This study aims to identify the topics of Islamic religious discourse and its objectives in the Jordanian daily press. In order to achieve this end, the researcher used the descriptive approach, as the study was conducted within the framework of sample survey approach of Islamic religious discourse published in the Jordanian daily newspapers which are (Al-Ra'i - Ad-Dustour - Al-Ghad) which is included in the religious page issued weekly (every Friday). The study tool was the content analysis. Among the results reached: First: the presence of a clear variation in the percentage of published topics, which gives the impression that there is no strategy regulating the journalistic publishing process of Islamic religious discourse topics, 
which must be determined - originally - according to a specific mechanism that depends on the priorities of the topics to be published. Second: Addressing many of the topics came out inadequate and unsuccessful, and the reason beyond this might be due to the focus on some aspects and not others. Third: The three newspapers (al-Ra'i - Ad-Dustour - al-Ghad) focused on specific goals and disregarded others. Fourth: Every newspaper has been singled out with the goal that it cares more about it, while neglecting other goals, or marginalizing it by giving it a low percentage in terms of the size of the publication. Fifth: other objectives than the previous ones did not receive sufficient attention, even though they are the main objectives of Islamic religious discourse. Sixth: Lack of topics related to community reform and the treatment of its religious pages at the level of the newspaper itself and the newspapers altogether.

A study carried out by (Fathi, 2012) entitled "Analysis of the content of the website (Institute of Islamic Topics) affiliated to the German Evangelical Union. The study aims to analyze the content of one of the Orientalist sites that were established by the Institute of Islamic Topics of the German Evangelical Union. This site is characterized by that it targets the Germans themselves. The study found that Muslims have reverted to caring for their religion: moreover, the last two decades have witnessed a doubling of a return to awareness of Islam accompanied with a re-orientation of the values of Islamic culture spread in the Middle East. In some large cities, we see closed societies representing "Islamic ghetto" in the strict sense of the word, and it seems that the readiness for further integration is still in constant decline. With Muslims feeling their rejection by German society and the feeling that the homeland is no longer here (Germany) nor there (the original homeland), Islam has again returned to form one of the identity determinants for many Muslims. Many Muslims today believe that Islam is the only alternative to an atheist German society.

A study carried out by (Rehman, et.al., 2012) entitled "The role of the media and information technology in Islamic education" The study aimed to shed light on the role of the media and how it can be used to spread the true message of Islam calling for peace and love and its education how to promote the Prophetic Sunnah. The study found that the use of modern technology in educational institutes to teach Islamic values is most effective as the media and information technology make it very easy for people to access information on almost any topic in the world. The media also plays the biggest role in spreading the call to Islam and educating people about Islamic schools of thought.

A closer look at the previous studies, we find that it focused on religious media in some topics, and did not focus on the rest of religious topics, without addressing other important topics from a religious point of view, such as social, political, educational, economic, and human rights topics . To find out about these various topics, the study analyzed the contents of the Hashemite Scientific Councils to come up with recommendations that would contribute to the development of the Hashemite Scientific Councils and their religious mission.

\section{Theoretical Framework}

We need to use theory to help understand the subject matter of the study. In this study, we need to use the theory of prioritization of any media, whatever its plan, strategy and goals on which it is based. A media cannot succeed without setting this plan by which all topics and topics are categorized according to importance and priority (Johar Q., 2016).

The idea of prioritizing emerges from the existence of a relationship between the way the media presents different topics and the arrangement of topics according to their importance for the masses, so the media focuses on the topics that are expected to be among the priorities of public interests.

The media draws attention to what is important for them to put it within the same degree for the masses so it focus on certain topics and that covering these topics is only evidence of its importance. Shedding light on certain events or personalities and working to repeat them contributes to making them important for the audience, and thus this audience begins adopting these events and personalities and arranging them according to the arrangement and selection made by the media according to the theory of prioritization or the so-called agenda, which leads to the audience 
contributing to its interaction with these events and topics raised.

It can be said that the Hashemite Scientific Councils cannot cover and follow all religious topics, while those in charge of the councils choose topics that serve the goals of the The Ministry of Awqaf and Islamic Affairs (Amayreh, 2020).

\section{Methodology}

The study has applied the Descriptive Approach, which is concerned with researching the current situation or incident, and determines the correlative relationships between the variables that affect this phenomenon. From this comprehensive perception, it is possible to predict and conclude with the future conditions that this phenomenon will lead to. The study used the type of content analysis included under the survey method in the descriptive approach, where the content analysis is one of the common research methods used in media studies.

\subsection{Population}

The study population consists of the sessions of the Hashemite Scientific Councils held since (1999) and is still broadcast until the year (2019) in the month of Ramadan each year at a rate of (4-5) councils annually, and they were usually held every Friday from (1.30pm - 3.0opm), which numbered (96) councils until the date of the study. Table (1) clarifies this.

Table (1): Shows the conclusion of the Hashemite Scientific Councils

\begin{tabular}{|c|c|c|c|c|c|c|c|c|c|c|}
\hline \multirow{3}{*}{$\begin{array}{l}\text { The Hashemite } \\
\text { Scientific Councils }\end{array}$} & \multicolumn{7}{|c|}{ Day of conclusion } & \multicolumn{2}{|r|}{ Time } & \multirow[b]{2}{*}{$\begin{array}{c}\text { Average } \\
\text { time in } \\
\text { minutes }\end{array}$} \\
\hline & 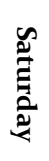 & $\underset{ٍ}{\mathscr{Z}}$ & $\begin{array}{l}3 \\
0 \\
0 \\
2\end{array}$ & 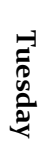 & 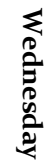 & 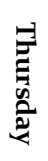 & . & am & pm & \\
\hline & & & & & & & $\sqrt{ }$ & & $3.00-1.30$ & 1.30 \\
\hline
\end{tabular}

\subsection{The study sample}

A "random sample" consisting of (48) councils has been chosen from the Hashemite Scientific Councils held since (1999-2019); two councils a month, whether two weeks in a row or two weeks apart.

\subsection{The Study tool}

Content analysis form: The researcher designed a form to analyze the content of the Hashemite Scientific Councils that the researcher chose from the councils held since (1999-2019), to analyze the content contained in these councils from religious, social, economic, educational, political, human rights and dignity topics.

\subsection{Statistical analysis}

The data analysis was based on the Descriptive Approach, which uses frequencies and percentages in addition to using the $\mathrm{Chi}^{2}$ test to identify the significance of differences in the role of the Hashemite scientific councils in the Hashemite Kingdom of Jordan in disseminating the true image of Islam. 


\section{Results}

The results of the study were reached through the use of frequencies and percentages, and supporting the results with some graphs that clarify the role of the Hashemite scientific councils in the Hashemite Kingdom of Jordan in disseminating the true image of Islam. The following are the results of the study:

\subsection{Results related to the role of Hashemite scientific councils in presenting topics in general}

Frequencies and percentages were extracted and the $\mathrm{Chi}^{2}$ test was used to identify the role of the Hashemite Scientific Councils in presenting the topics in general, as shown in Table 2 below:

Table (2): Shows the role of the Hashemite Scientific Councils in presenting the topics in general, in descending order

\begin{tabular}{|c|c|c|c|c|}
\hline $\begin{array}{l}\text { The role of the Hashemite Scientific Councils in } \\
\text { presenting the topics in general }\end{array}$ & Frequency & $\%$ & $\mathrm{Chi}^{2}$ & Significance \\
\hline Religious topics & 4503 & .680 & \multirow{7}{*}{$9 \cdot 541$} & \multirow{7}{*}{ *o.oo } \\
\hline Political topics & 1090 & .165 & & \\
\hline Educational topics & 322 & .049 & & \\
\hline Social topics & 311 & .047 & & \\
\hline Economic topics & 235 & .035 & & \\
\hline Human rights and dignity topics & 162 & .024 & & \\
\hline Total & 6623 & 100.0 & & \\
\hline
\end{tabular}

The results of the study in Table (2) showed that the Hashemite Scientific Councils have a role in spreading the true image of Islam. Religious topics have ranked first representing( 68\%) of the general content of topics, and secondly, political topics which came with a percentage of (16.5\%) of the general content of topics, and thirdly, educational topics which came with a percentage of (4.9\%), while fourth came social topics representing $(4.7 \%)$, followed by economic topics with a percentage of $(3.5 \%)$, while human rights and dignity topics came in the last rank, having obtained a percentage of $(2.4 \%)$ of the general total of topics .

The results showed that there are statistically significant differences at the level of significance (0.05) in the presentation of topics in general by the Hashemite Scientific Councils, where the topics were highly oriented towards religious topics, and then towards political topics, as shown in Figure (1).

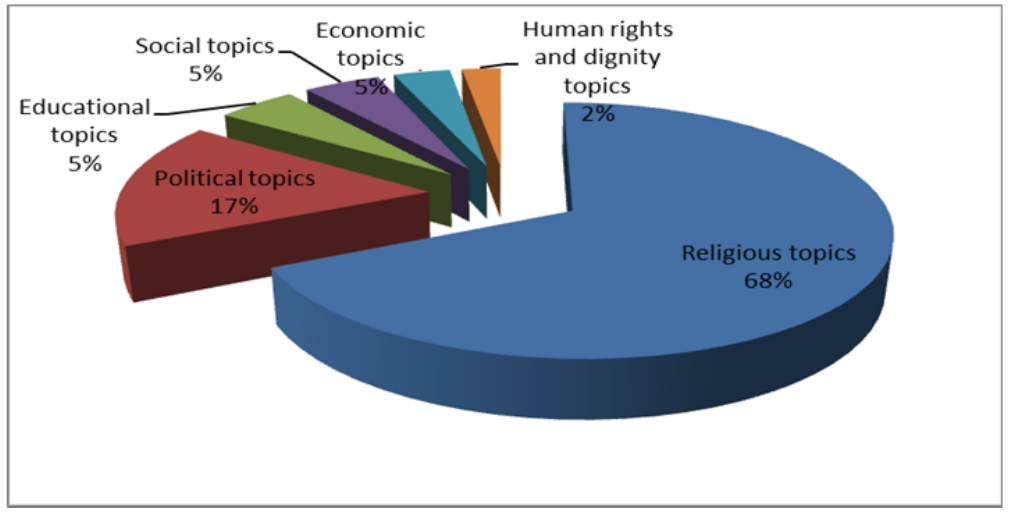

Figure (1): Shows the role of the Hashemite Scientific Councils in presenting topics in general 
The following is an explanatory presentation of the sub-content of each of the study sample topics:

First: The role of the Hashemite scientific councils in presenting religious topics:

Frequencies and percentages were extracted and the $\mathrm{Chi}^{2}$ test was used to identify the role of Hashemite Scientific Councils in presenting religious topics, as shown in Table 3 below:

Table (3): Shows the role of the Hashemite Scientific Councils in presenting religious topics

\begin{tabular}{|c|c|c|c|c|}
\hline $\begin{array}{l}\text { The role of the Hashemite Scientific Councils in the } \\
\text { Hashemite Kingdom of Jordan in presenting religious topics }\end{array}$ & Frequency & $\%$ & $\mathrm{Chi}^{2}$ & Significance \\
\hline Citizenship from an Islamic perspective & 1148 & .255 & \multirow{11}{*}{12.154} & \multirow{11}{*}{ *o.oo } \\
\hline Manifestations of the tolerant message of Islam & 898 & .199 & & \\
\hline Topics of the Holy Qur'an, Sunnah and Worship & 626 & .139 & & \\
\hline Values of Islam & 599 & .133 & & \\
\hline Islamic faith and jurisprudence & 397 & .088 & & \\
\hline Standards of integrity and transparency in Islamic law & 332 & .074 & & \\
\hline The philosophy of jihad in Islam & 192 & .043 & & \\
\hline Fatwa and sermons in Islam & 129 & .029 & & \\
\hline The problem of governance in contemporary Islamic thought & 93 & .021 & & \\
\hline Topics of religious discourse & 89 & .020 & & \\
\hline Total & 4503 & 100.0 & & \\
\hline
\end{tabular}

The results of the study showed that the Hashemite Scientific Councils have a role in presenting religious topics. The presentation topics related to citizenship from an Islamic perspective has ranked first at a rate of $(25.5 \%)$ of the general content, and in the second place came the presentation of topics of tolerant aspects of Islam by $19.9 \%$ of the general content.

The content related to the presentation of religious topics varied, until the lowest content percentage of the (Topics of religious discourse), which scored a percentage of $(2 \%)$ of the general content, came in the penultimate rank. The content related to (The problem of governance in contemporary Islamic thought) scored (2.1\%) of the general content.

The results of the study showed that there were statistically significant differences in the coverage of religious topics, where the value of $\mathrm{Chi}^{2}$ was (12.154) and a statistical significance less than (o.05). The differences were in favor of the topics related to (citizenship from an Islamic perspective), as shown in Figure (2).

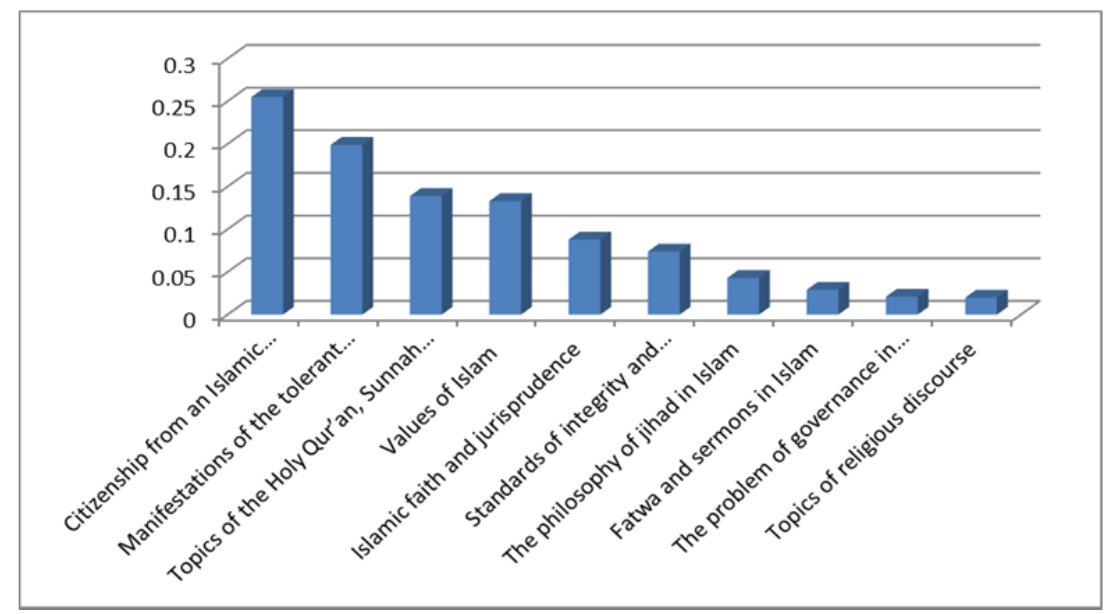

Figure No. (2): Shows the role of the Hashemite scientific councils in presenting religious topics 
Second: The role of the Hashemite Scientific Councils in presenting social topics

Frequencies and percentages were extracted and the $\mathrm{Chi}^{2}$ test was used to identify the role of the Hashemite Scientific Councils in presenting social topics, as shown in Table 4 below:

Table (4): Shows the role of the Hashemite Scientific Councils in presenting social topics

\begin{tabular}{|c|c|c|}
\hline The role of the Hashemite Scientific Councils in presenting social topics & Frequency & $\%$ \\
\hline Youth care and guidance & 27 & .087 \\
\hline providing citizens with housing and decent living & 26 & .084 \\
\hline Youth, their opinions and made them to the fore & 20 & .064 \\
\hline Raising children is a trump in the hands of Muslims & 19 & .061 \\
\hline Taking into account the conditions, conditions and special needs of the community & 17 & .055 \\
\hline Islamic education in the face of the contemporary challenges & 17 & .055 \\
\hline The role of mosques in raising family behavior and developing good morals & 17 & .055 \\
\hline Community happiness is achieved in meeting and communicating & 16 & .051 \\
\hline Spending money on foster care of orphans, helping the needy, and assisting those in debt. & 16 & .051 \\
\hline Building programs for young people during their vacation to serve the country & 15 & .048 \\
\hline Honesty while raising children & 13 & .042 \\
\hline Fulfilling the needs of the poor and planning their future & 13 & .042 \\
\hline Couples understand each other & 12 & .039 \\
\hline The family's focus on justice and giving rights to their owners & 12 & .039 \\
\hline The role of women and youth in the renaissance & 11 & .035 \\
\hline The marital relationship is sacred and good treatment between the spouses & 9 & .029 \\
\hline Home security stabilization & 9 & .029 \\
\hline Family responsibility, father and mother responsibility & 8 & .026 \\
\hline Emphasis on character building and formation & 7 & .023 \\
\hline Women are not a separate entity from the Muslim community & 7 & .023 \\
\hline Start changing yourself to set an example for your family & 7 & .023 \\
\hline Personal Status Law & 5 & .016 \\
\hline Keeping the secrets of the family & 4 & .013 \\
\hline Modern social theories have not provided more than what the Islam did & 4 & .013 \\
\hline Total & 311 & 100.0 \\
\hline
\end{tabular}

The results of the study showed that the Hashemite Scientific Councils have a role in presenting social topics, as the topics that have addressed providing citizens with housing and decent living ranked first $(8.4 \%)$ of the general content, and in the second rank came the presentation of topics that consider conditions and needs of society $(5 \cdot 5 \%)$ of the general content.

In the last rank, the content dealt with topics of modern social theories, which did not provide more than what Islam has provided, at a percentage of (1.3\%) of the general content.

Third: The role of the Hashemite Scientific Councils in presenting economic topics

Frequencies and percentages were extracted and the Chi ${ }^{2}$ test was used to identify the role of the Hashemite Scientific Councils in presenting economic topics, as shown in Table 5 below:

Table (5): Shows the role of the Hashemite scientific councils in presenting economic topics

\begin{tabular}{|l|r|c|}
\hline The role of the Hashemite scientific councils in presenting economic topics & Frequency & $\%$ \\
\hline Good treatment and the prohibition of fraud in buying and selling & 47 & .200 \\
\hline Honesty and trustworthiness in buying and selling & .094 \\
\hline Achieving economic development & 22 \\
\hline Building the economy of the state & $\mathbf{1 4}$ \\
\hline The legality of the Waqf (endowment) in Islam & 13 \\
\hline The companion Othman bin Affan has settled the debts of those in debt and the needy. & .055 \\
\hline Psychology and values of the profession. & 12 & .051 \\
\hline
\end{tabular}




\begin{tabular}{|c|c|c|}
\hline The role of the Hashemite scientific councils in presenting economic topics & Frequency & $\%$ \\
\hline Strong economic growth through availability of security & \begin{tabular}{|l|l}
11 & \\
\end{tabular} & .047 \\
\hline Businessmen and corporate initiatives in education and infrastructure & 10 & .043 \\
\hline The prophetic approach to preserving public money & 10 & .043 \\
\hline Rationalization of consumption and environmental preservation & 10 & .043 \\
\hline Create professions and jobs and their provisions & 9 & .038 \\
\hline Hunger, poverty and unemployment & 8 & .034 \\
\hline Investing the lands of Muslims & 7 & .030 \\
\hline Sincerity at work & 7 & .030 \\
\hline work perfection & 6 & .026 \\
\hline The best nation is the one that eats of what it seeds so that the enemies do not control the economy & 5 & .021 \\
\hline The importance of unlimited joint stock companies & 5 & .021 \\
\hline National and per capita income & 5 & .021 \\
\hline Increment of production & 4 & .017 \\
\hline Eliminate taxes that harm people & 4 & .017 \\
\hline Work secrets and keeping them confidential & 4 & .017 \\
\hline Total & 235 & 100.0 \\
\hline
\end{tabular}

The results of the study showed that the Hashemite Scientific Councils have a role in presenting economic topics. The presentation of topics related to good treatment and the prohibition of fraud in buying and selling has ranked first, at $20 \%$ of the general content. Presenting the topics of honesty and trustworthiness in buying and selling has ranked second (9.4\%) from the general content.

In the last place came the content that dealt with topics of work secrets and keeping them confidential, at $1.7 \%$ of the general content.

Fourth: The role of the Hashemite Scientific Councils in presenting political topics

Frequencies and percentages were extracted and the $\mathrm{Chi}^{2}$ test was used to identify the role of the Hashemite Scientific Councils in presenting political topics , as shown in Table 6 below:

Table (6): Shows the role of the Hashemite Scientific Councils in presenting political topics

\begin{tabular}{|c|c|c|}
\hline the role of the Hashemite Scientific Councils in presenting political topics & Frequency & $\%$ \\
\hline Juristic provisions related to Al-Quds and Al-Aqsa Mosque & 61 & .56 \\
\hline Coexistence between Muslims and non-Muslims in non-Muslim countries & 33 & .030 \\
\hline Rejection of bombing incidents and actions that offend Islam & 32 & .029 \\
\hline How do we face rumors in an age when information is no longer monopolized & 32 & .029 \\
\hline Renouncing wars and destruction through dialogue & 31 & .028 \\
\hline The Organization of Islamic Cooperation highlights tolerance between Muslims themselves and others & 29 & .027 \\
\hline $\begin{array}{l}\text { Modern terminology, its problem, and its impact on Muslims in Western countries, which detract } \\
\text { from their rights, such as clash, conflict, and Judging others as unbelievers }\end{array}$ & 27 & .025 \\
\hline Models for Muslims decision-making in Western countries & 27 & .025 \\
\hline Wisdom and kindness in dialogue does not mean changing the pillars and principles of Islam & 27 & .025 \\
\hline The real obstacle to the rise of Islam is the absence of freedom & 26 & .024 \\
\hline Communication and dialogue with the other and giving a true picture of Islam & 25 & .023 \\
\hline Reconstruction and maintenance of Al-Aqsa Mosque & 25 & .023 \\
\hline Clash of Civilizations - Dialogue of Civilizations to introduce Islam & 25 & .023 \\
\hline "Mounts are not saddled for except to (travel to) three Masjids (mosques) : (Al-Aqsa Mosque ) & 24 & .022 \\
\hline The required dialogue through seminars and media & 24 & .022 \\
\hline Security is one of God's blessings, and it intervenes in all aspects of life & 23 & .021 \\
\hline Encouraging dialogue and communication between Islam and Christianity & 21 & .019 \\
\hline Arab nationalism and building patriotism & 21 & .019 \\
\hline The end justifies the means and politics is a dirty game & 21 & .019 \\
\hline How to build awareness and political guidance & 20 & .018 \\
\hline Security is the key to well-being for the whole world & 20 & .018 \\
\hline Dialogues with non-Muslims show commonalities between both parties & 20 & .018 \\
\hline Muslims killed in the yards of Al-Aqsa Mosque & 19 & .017 \\
\hline
\end{tabular}




\begin{tabular}{|c|c|c|}
\hline the role of the Hashemite Scientific Councils in presenting political topics & Frequency & $\%$ \\
\hline The status of Al-Quds in Islam & \begin{tabular}{|l|l|l}
18 \\
\end{tabular} & .017 \\
\hline Clinging to the homelands and not giving in to sectarianism. & 17 & .016 \\
\hline A strategic team for consultation in a sedentary state to discuss turmoil in a precarious state & 17 & .016 \\
\hline Lying and gossip are spread through social media & 17 & .016 \\
\hline Western material civilization lacks the spiritual and moral aspect & 17 & .016 \\
\hline Amman civilizational message in embodying the concepts of dialogue and coexistence with the other & 16 & .015 \\
\hline Western thought benefited from Islamic civilization and the holistic view of the universe & 16 & .015 \\
\hline Islamophobia is a misunderstanding of religion, a contradiction between thought and behavior & 16 & .015 \\
\hline The journey of Isra and Mi'raj & 16 & .015 \\
\hline Differences among Muslims, the enemy exploits them and keeps us away from religion & 16 & .015 \\
\hline Globalization is subject to ideological topics & 16 & .015 \\
\hline Ideology of control over societies & 16 & .015 \\
\hline Achieving homeland security, stability and development & 15 & .014 \\
\hline Spreading social security and rejecting violence & 15 & .014 \\
\hline Provision of military, psychological, social, and economic security until the concept ( fear God ) is achieved & 15 & .014 \\
\hline Islamophobia, a recent issue & 15 & .014 \\
\hline Hashemite custodianship of the city of Al-Quds & 15 & .014 \\
\hline Our Islamic civilization has mental, spiritual and social spirit & 15 & .014 \\
\hline Democracy; the state makes the decision after consultation & 14 & .013 \\
\hline Modern civilization is responsible for many achievements & 14 & .013 \\
\hline $\begin{array}{l}\text { Parliamentary assemblies must be the pulse of the nation - when are they considered legitimate? - it } \\
\text { is not enough to elect }\end{array}$ & 13 & .012 \\
\hline Building strong state institutions is the implementation of God's rule & 12 & .011 \\
\hline What threatens human security, lack of religions and justice & 12 & .011 \\
\hline The Dome of the Rock is the most prominent religious site & 12 & .011 \\
\hline Cultural interaction and civilization construction in the world & 11 & .010 \\
\hline Contributing to the civilizational, cultural and humanitarian construction & 11 & .010 \\
\hline The most prominent modern problems are awakening, vigilance, renaissance, civilization & 11 & .010 \\
\hline Modernity Project & 11 & .010 \\
\hline Building international relations & 11 & .010 \\
\hline Dialogue and peace between cultures and religions & 10 & .009 \\
\hline Political systems limit the space for religion & 10 & .009 \\
\hline Provision of social and political security & 10 & .009 \\
\hline There is a Security Council, and there must be a Social Security Council & 9 & .008 \\
\hline The separation of religion and state & 7 & .006 \\
\hline Despotism freezes the mind and thought & 6 & .006 \\
\hline Republican regimes are a pinnacle of despotism & 5 & .005 \\
\hline Total & 1090 & 100.0 \\
\hline
\end{tabular}

The results of the study showed that the Hashemite Scientific Councils have a role in presenting political topics. The presentation of topics related to Juristic provisions related to Al-Quds and AlAqsa Mosque have ranked first, at a percentage of $(5.6 \%)$ of the general content. In second place came the presentation of topics of Coexistence between Muslims and non-Muslims in non-Muslim countries, at a percentage of $(3 \%)$ of the general content.

In the last place came the content of "Republican regimes are a pinnacle of despotism" with a percentage of (0.5\%) of the general content.

Fifth: The role of the Hashemite Scientific Councils in presenting educational topics

Frequencies and percentages were extracted and the $\mathrm{Chi}^{2}$ test was used to identify the role of the Hashemite Scientific Councils in presenting educational topics, as shown in Table 7 below: 
Table (7): Shows the role of the Hashemite Scientific Councils in presenting educational topics

\begin{tabular}{|l|c|c|}
\hline The role of the Hashemite Scientific Councils in presenting educational topics & Frequency & $\%$ \\
\hline The mind leads to knowledge & 24 & .075 \\
\hline Collective ijtihad (discretion) & 23 & .071 \\
\hline The state is interested in the scientific movement such as schools and universities & 23 & .071 \\
\hline The Scholars' Consultation & 23 & .071 \\
\hline Ethics of knowledge, sincerity and understanding & 22 & .068 \\
\hline Shura (consultation) in science & 22 & .068 \\
\hline Trust in science & 22 & .068 \\
\hline Food for the mind It is science & 21 & .065 \\
\hline Allah calls for learning & 19 & .059 \\
\hline Scientists, science and piety remain & 17 & .053 \\
\hline Building cadres and scientific expertise & 17 & .053 \\
\hline Good example in schools and universities & 16 & .050 \\
\hline Scientific research and providing a scientific climate for researchers & 16 \\
\hline The curricula used need to be changed in order for thinking to change & 16 & .050 \\
\hline We need technology education, medicine, and astronomy & 16 & .050 \\
\hline If you want to win this life and the hereafter you should learn & 15 th & .047 \\
\hline New sciences, syntactic, sociology, jurisprudence & 13 & .040 \\
\hline The ignorant argues with the scientists & 7 & .022 \\
\hline Total & 6 & .019 \\
\hline
\end{tabular}

The results of the study showed that the Hashemite Scientific Councils have a role in presenting educational topics, and the presentation of subjects that have a relationship with " The mind leads to knowledge has ranked first $(7.5 \%)$ of the general content. In second place came the presentation of the topics of "Collective ijtihad (discretion)" with a percentage of (7.1\%) of the general content.

In the last place came the content that dealt with topics of "ignorant argues with the scientists", with a percentage of $(1.9 \%)$ of the general content.

Sixth: The role of the Hashemite Scientific Councils in presenting human rights and dignity topics

Frequencies and percentages were extracted and the $\mathrm{Chi}^{2}$ test was used to identify the role of the Hashemite Scientific Councils in presenting human rights and dignity topics, as shown in Table 8 below:

Table (8): Shows the role of the Hashemite Scientific Councils in presenting human rights and dignity topics

\begin{tabular}{|c|c|c|}
\hline The role of the Hashemite Scientific Councils in presenting human rights and dignity topics & Frequency & $\%$ \\
\hline Islam emphasized human rights through freedom of opinion, expression, and belief. & 25 & .154 \\
\hline Islam called for fairness, not equality; a man remains a man, and a woman remains a woman & 18 & .111 \\
\hline Some human rights, according to opinions, are rejected by Islam, such as homosexuality and suicide. & 17 & .105 \\
\hline Building humanity is more important than building constructions & 16 & .099 \\
\hline Islam prohibited discrimination based on color and gender. & 14 & .086 \\
\hline Responsibility is shared between men and women in terms of rights and duties & 13 & .080 \\
\hline The rights of the universes are greater than human rights & 11 & .068 \\
\hline Islam preceded the International Declaration of Human Rights & 11 & .068 \\
\hline $\begin{array}{l}\text { Human rights in Islam were crystallized in the supreme legitimate purposes such as self-preservation, } \\
\text { protection of mind, protection of religion, dignity and freedom. }\end{array}$ & 9 & .56 \\
\hline The relationship between rights on the one hand and freedoms on the other. & 9 & .56 \\
\hline Islam raises human rights to the point of obligations and duties. & 7 & .043 \\
\hline Islam honors a human being with the sanctity of blood and money. & 7 & .043 \\
\hline The rights of Allah and the rights of people are two sides of the same coin. & 5 & .031 \\
\hline Total & 162 & 100.0 \\
\hline
\end{tabular}


The results of the study showed that the Hashemite Scientific Councils have a role in presenting topics of human rights and dignity. The presentation of topics that dealt with "Islam emphasized human rights through freedom of opinion, expression, and belief" has ranked first (15.4\%) of the general content. The presentation of topics "Islam called for fairness, not equality; a man remains a man, and a woman remains a woman " has ranked second with a percentage of $(11.1 \%)$ of the general content.

In the last place came the content that dealt with topics of "The rights of Allah and the rights of people are two sides of the same coin", with a percentage of $(3.1 \%)$ of the general content.

\section{Discussion}

The results of the study showed that the Hashemite Scientific Councils have a role in disseminating the true image of Islam, as disseminating of religious issues has ranked first, and this may be due to, according to the researcher's opinion, that the Hashemite Scientific Councils have their primary goal as "a religious goal", especially since it is held every Friday of Ramadan.

This result is consistent with the study carried out by (Rehman et.al., 2012) in their study on "the role of the media and information technology in Islamic education". This result is also consistent with the study carried out by (Rammal \& Mikhael, 2017) " the role that religious media owned by religious institutions play through political, religious, social and other messages, and their compatibility with the requirements of civil peace." Referring to the most prominent religious topics covered by the Hashemite Scientific Councils, "citizenship from an Islamic perspective" has scored the highest value of frequency due to its importance in the reality of society and thus has been repeatedly emphasized by the Hashemite Scientific Councils. In addition, the Hashemite Scientific Councils were concerned with the religious issues that raised "tolerant aspects of Islam", and this is consistent with the study carried out by (Rhman et al., 2012) "How the media can contribute to spreading the true message of Islam and preaching the Islamic faith that calls for peace and love and teaching them.

Among the content of the religious topics that the Hashemite Scientific Councils dealt with , the topics of the Holy Qur'an, the Sunnah of the Prophet, and acts of worship. This is due to that such topics are the basics of Islam. This is consistent with the results of the study carried out by (Zayed, 2016) in which he stressed that Islam includes major contents, most notably ((general guidance content, values content, juristic content, intentional content, and sunnah content)) .The results showed the interest of religious subjects in the values of Islam, as the values are considered the "backbone" of Islam, and this is consistent with the results of the study carried out by (Zayed, 2016), in which he addressed that Islam includes the moral content. This interest in these standards came due to the suffering of societies today from issues of bribery and corruption on a large scale, and this result differs with the results of the study carried out by (Abu Ghazaleh, 2013), in which he emphasized the lack of issues related to community reform in Islamic religious discourse.

The study concluded that there is a great interest in social issues by the Hashemite Scientific Councils. According to the researcher's opinion, social issues are no less important than religious issues, because they were addressed from an Islamic perspective. The Islamic religion is an approach and life in all respects, whether religious, social, economic, cultural, and others. It is not possible to separate the social aspect from the other aspects, and therefore, it is normal for the scientific councils to address social issues that relate to the life of societies, and one of the most prominent interest in social issues was dealing with some important topic such as providing citizens with housing and decent living, as well as caring for the segments of society, including the youth, how to care for them and meet their needs.

On the other hand, the Hashemite Scientific Councils focused on family education and building positive relationships in addition to caring for orphans and the needy. Islam did not miss the integrated care of all segments of society, and this is consistent with the study (Rammal \& Mikhael, 2017) in which they emphasized the role of the religious media plays on broadcasting social and other 
messages and their conformity with the requirements of the civil peace, and contradicts the study (Abu Ghazaleh, 2013) in which he emphasized that dealing with issues is inadequate and not sufficient.

The study showed the interest of the Hashemite Scientific Councils in economic issues, as they dealt with many economic issues from an Islamic perspective, most notably good treatment in buying and selling, achieving economic development, legality of waqf "endowment", capital and companies, rationalization of consumption, poverty, unemployment and other economic issues. According to the opinion of the researcher, Islam is a comprehensive religion which covers and addressed all aspects of life.

Islam has realized for centuries the economic aspect and its importance for societies. There are many ayas "Quranic verses" that emphasize the importance of economic aspects in human life. Allah said in the Holy Qur'an, "But Allah has permitted trade and has forbidden interest "(Quran 2:275). The noble Sunnah mentioned some hadiths (prophet's speech) that emphasize the importance of the economic aspects of a person's life. Prophet Mohammad said: "Nobody has ever eaten a better meal than that which one has earned by working with one's own hands. The Prophet of Allah, David used to eat from the earnings of his manual labor". (Abu al-Qasim, 2017).

The results of the study showed the depth of Hashemite Scientific Councils interest in political issues including (Coexistence between Muslims and non-Muslims in non-Muslim countries, Juristic provisions related to Al-Quds and Al-Aqsa Mosque, rejection of bombing incidents and actions that offend Islam, how do we face rumors in an age when information is no longer monopolized, modern terminology, its problem, and its impact on Muslims in Western countries, which detract from their rights, such as clash, conflict, and Judging others as unbelievers). These issues, according to the theory of prioritization, are among the priorities of the political issues that the Islamic community needs in arranging its internal and external relations with other societies. The Hashemite Scientific Councils clarified the importance of political issues from an Islamic perspective.

In this regard, the study showed that Islam is an integrated approach in all aspects of life. This result is consistent with the study carried out by (Rammal \& Mikhael, 2017) that emphasized the importance of religious media discourse aimed at spreading political messages and their compatibility with the requirements of civil peace.

The results of the study showed the interest of the Hashemite Scientific Councils in educational subjects, most notably (the mind leads to knowledge, interest in schools and universities, consultation of scholars, and building cadres, scientific expertise and scientific research). This Hashemite Scientific Councils' interest in such topics, according to the researcher's opinion, stems from that Islam is based on knowledge which every male and female shall seek to acquire. Allah said in the Holy Quran: "Allah will rise up, to (suitable) ranks (and degrees), those of you who believe and who have been granted (mystic) Knowledge. And Allah is well-acquainted with all ye do"( Al-Mujadila: Quran 58:11) and the Islamic religion has spread through the spread of knowledge, This result is consistent with the results of a study carried out by (Fathi, 2012) in which he emphasized the increasing spread of Islam, and that Islam is witnessing a doubling in people's awareness of Islam.

The results of the study showed great interest in presenting human rights issues and dignity by the Hashemite Scientific Councils, including (freedom of opinion, equality, non-discrimination and responsibility in terms of rights and duties). This interest comes according to the researcher's opinion that the message of Islam was based on the return of rights and duties. Islam preceded all international institutions and declarations regarding human rights, and there are many Quranic Aya urged the protection and honor of human rights, as Allah said Surat Al-Isrsa'a: (Quran 17:70): "We have honoured the sons of Adam".

Human rights issues are among the priorities of Islam and based on it, and this is consistent with the interpretation of the prioritization theory. 


\section{Conclusion}

We do thank Allah for finishing the topic the role of the Hashemite Scientific Councils in the Hashemite Kingdom of Jordan in Reflecting the True Image of Islam. It was a striving journey to enrich the mind. Al-Asfahani (scholar) says: "Anyone who authors a book will be always subject to criticism." We recognize that humans cannot reach perfection.

\section{Recommendations}

The recommendations of the study came from the results it reached, as follows:

1. Those who are in charge of holding Councils by the Ministry of Awqaf and Islamic Affairs shall pay attention to vital issues, such as health and cultural issues and human rights.

2. Conducting scientific research and studies that show the role of the Hashemite Scientific Councils in all aspects of life.

3. Activating the Hashemite Scientific Councils and generalizing their experience in the Arab and Islamic world.

4. The various media and means of communications shall adopt the message of the Hashemite Scientific Councils in disseminating the true image of the Islamic religion.

\section{References}

The Holy Quran.

Abdul Karim Al-Debisi (2017) Media Studies in Content Analysis, Dar Al-Masirah, Amman, p. 25

Abu al-Qasim, Muhammad al-Tahir, Prophetic Hadiths in Economics and Financial Transactions, Economic Readings in the Light of the Qur'an and Sunnah, 2017, p. 13 http: drive.google.com/File/d,.

Ahmed Fathi, 2012 titled Content Analysis of the website (Institute of Islamic Issues) of the German Evangelical Union, published on the website http: www.alukah.net

Ahmed Zayed, 2016.the Structure of Islamic Discourse: A Study in Content and Function, Taibah University Journal: For Arts and Humanities, Fifth Year, Issue (11), pp. 297-303.

Ibn Manẓūr, (2010), Lisān al-'Arab , Dar Sader, Beirut, Vol. 2, p. 241.

Johar Qashout, 2016, analysis of the content of the first pages in Jordanian daily newspapers, an analytical study, an unpublished Master Thesis from the Middle East University, Amman, Jordan.

Mohammad, Al-Amayreh, Advisor of the Ministry of Awqaf and Islamic Affairs, telephone call by researcher Dr. Khairieh Hamid Shnaikat

Nisreen Hassouneh (2014) Content Analysis, its concept, determinants and uses.Al-Alokah Network, pp. 1-5.

Publications of the Ministry of Awqaf and Islamic Affairs, (2020).

Rammal, A., Michael, T. (2017). The discourse of religious media oultlet and its consistency with principles of civil peace, UNDP, PP 1-34.

Rehman, A., Ahmad, Z., Sultan, S., Baloach, A. \& Khalid, I. (2012). The role of media \& information technology in Islamic education, European Journal of Social Sciences, ISSN 1450 - 2267,Vol. 32 No. 3, PP. 380 - 390.

Sherine Taqatqa, (2016), Definition of Islam, posted on https: //mawdoo3.com

The Jordanian Al Ghad newspaper, The Hashemite Scientific Councils, Jordanian-Ramadan tradition, 25/5/2018. 